University of Wollongong

Research Online

Australian Institute for Innovative Materials -

Papers

Australian Institute for Innovative Materials

$1-1-2014$

Conductivity and oxygen reduction activity changes in lanthanum strontium manganite upon low-level chromium substitution

George Tsekouras

University of Wollongong, georget@uow.edu.au

Artur Braun

Swiss Federal Laboratories for Materials Science and Technology

Follow this and additional works at: https://ro.uow.edu.au/aiimpapers

Part of the Engineering Commons, and the Physical Sciences and Mathematics Commons

Research Online is the open access institutional repository for the University of Wollongong. For further information contact the UOW Library: research-pubs@uow.edu.au 


\title{
Conductivity and oxygen reduction activity changes in lanthanum strontium manganite upon low-level chromium substitution
}

\author{
Abstract \\ On the timescale of solid oxide fuel cell (SOFC) system lifetime requirements, the thermodynamically \\ predicted low-level substitution of chromium on the B-site of $(\mathrm{La}, \mathrm{Sr}) \mathrm{MnO}_{3}$ could be a source of cathode \\ degradation underlying more overt and well-known chromium poisoning mechanisms. To study this \\ phenomenon in isolation, electronic conductivity $(\sigma)$ and electrochemical oxygen reduction activity of the \\ $\left(\mathrm{La}_{0.8} \mathrm{Sr}_{0.2}\right)_{0.98} \mathrm{Cr}_{x} \mathrm{Mn}_{1-x} \mathrm{O}_{3}$ model series $(x=0,0.02,0.05$ or 0.1$)$ were measured in air between 850 and \\ $650^{\circ} \mathrm{C}$. Depending on the extent of chromium substitution and the measurement temperature, \\ electrochemical impedance spectroscopy (EIS) results could be deconvoluted into a maximum of three \\ contributions reflecting possible limiting processes such as oxide ion transport and dissociative \\ adsorption. Chromium substitution resulted in lowered $\sigma$ (from $174 \mathrm{~S} \mathrm{~cm}^{-1}(x=0)$ to $89 \mathrm{~S} \mathrm{~cm}^{-1}(x=0.1$ ) \\ at $850{ }^{\circ} \mathrm{C}$ ) and a steady rise in associated activation energy $\left(E_{a}\right)$ (from $0.105 \pm 0.001 \mathrm{eV}(x=0)$ to $0.139 \pm$ \\ $0.001 \mathrm{eV}(x=0.1))$. From EIS analyses, ohmic and polarisation resistances increased, whilst Ea for the \\ overall oxygen reduction reaction also increased from $1.39 \pm 0.04 \mathrm{eV}(x=0)$ to $1.48-1.54 \pm 0.04 \mathrm{eV}$ upon \\ chromium substitution.

\section{Keywords} \\ level, conductivity, oxygen, reduction, activity, changes, chromium, lanthanum, substitution, strontium, \\ manganite, upon, low \\ Disciplines \\ Engineering | Physical Sciences and Mathematics

\section{Publication Details} \\ Tsekouras, G. \& Braun, A. (2014). Conductivity and oxygen reduction activity changes in lanthanum \\ strontium manganite upon low-level chromium substitution. Solid State lonics, 266 19-24.
}




\section{Conductivity and oxygen reduction activity changes in lanthanum strontium manganite upon low- level chromium substitution}

George Tsekouras and Artur Braun

Laboratory for High Performance Ceramics

Swiss Federal Laboratories for Materials Science and Technology

Überlandstrasse 129

Dübendorf 8600

Switzerland

*E: george.tsekouras@empa.ch

*T: +41 (0)58 7654952

Keywords: solid oxide fuel cell; lanthanum strontium manganite; chromium poisoning; electronic conductivity; electrochemical impedance spectroscopy

\section{Abstract}

On the timescale of solid oxide fuel cell (SOFC) system lifetime requirements, the thermodynamically predicted low-level substitution of chromium on the $\mathrm{B}$-site of $(\mathrm{La}, \mathrm{Sr}) \mathrm{MnO}_{3}$ could be a source of cathode degradation underlying more overt and well-known chromium poisoning mechanisms. To study this phenomenon in isolation, electronic conductivity $(\sigma)$ and electrochemical oxygen reduction activity of the $\left(\mathrm{La}_{0.8} \mathrm{Sr}_{0.2}\right)_{0.98} \mathrm{Cr}_{x} \mathrm{Mn}_{1-x} \mathrm{O}_{3}$ model series $(x=0,0.02,0.05$ or 0.1$)$ were measured in air between 850 and $650{ }^{\circ} \mathrm{C}$. Depending on the extent of chromium substitution and the measurement temperature, electrochemical impedance spectroscopy (EIS) results could be deconvoluted into a maximum of three contributions 
reflecting possible limiting processes such as oxide ion transport and dissociative adsorption. Chromium substitution resulted in lowered $\sigma$ (from $174 \mathrm{~S} \mathrm{~cm}^{-1}(x=0)$ to $89 \mathrm{~S} \mathrm{~cm}^{-1}(x=0.1)$ at $850{ }^{\circ} \mathrm{C}$ ) and a steady rise in associated activation energy $\left(E_{\mathrm{a}}\right)$ (from $0.105 \pm 0.001 \mathrm{eV}(x=0)$ to $0.139 \pm 0.001 \mathrm{eV}(x=0.1)$ ). From EIS analysis, ohmic and polarisation resistances increased, whilst $E_{a}$ for the overall oxygen reduction reaction also increased from $1.39 \pm 0.04 \mathrm{eV}(x=0)$ to $1.48-1.54 \pm 0.04 \mathrm{eV}$ upon chromium substitution.

\section{Introduction}

Solid oxide fuel cells (SOFCs) are promising for the distributable and efficient conversion of chemical energy (e.g. from natural gas, biogas, liquefied petroleum gas) to electrical energy, and could thus play an important role in lowering greenhouse gas emissions. However, SOFCs can suffer from a number of stability problems, including chromium poisoning of the widely employed cathode based on the perovskite oxide ( $\mathrm{La}, \mathrm{Sr}) \mathrm{MnO}_{3}$ by chromium-containing metallic alloy interconnects. Numerous studies (e.g. [1-20]) have considered the severity of chromium poisoning of ( $\mathrm{La}, \mathrm{Sr}) \mathrm{MnO}_{3}$-based cathodes depending on whether the SOFC is operated under load or is held at open-circuit, whether the air supplied to the cathode is dry or humidified, and depending on the interconnect metallic alloy used (Inconel 600, Cr5Fe1Y ${ }_{2} \mathrm{O}_{3}$, Crofer22APU, RA446, 17-4 stainless steel, AISI 441, SUS430, ITM or ZMG232).

Chromium poisoning of $(\mathrm{La}, \mathrm{Sr}) \mathrm{MnO}_{3}$-based SOFC cathodes includes the initial formation of $\mathrm{Cr}_{2} \mathrm{O}_{3(\mathrm{~s})}$ on the interconnect surface, volatilisation of $\mathrm{Cr}_{2} \mathrm{O}_{3(\mathrm{~s})}$ to $\mathrm{CrO}_{3(\mathrm{~g})}$ and $\mathrm{CrO}_{2}(\mathrm{OH})_{2(\mathrm{~g}) \text {, }}$ reaction of chromium species with ( $\mathrm{La}, \mathrm{Sr}) \mathrm{MnO}_{3}$, and deposition of volatile chromium species as $\mathrm{Cr}_{2} \mathrm{O}_{3(\mathrm{~s})}$ at triple-phase-boundary (TPB) active sites. Regarding the reaction of chromium species with $(\mathrm{La}, \mathrm{Sr}) \mathrm{MnO}_{3}$, formation of the spinel $(\mathrm{Cr}, \mathrm{Mn})_{3} \mathrm{O}_{4}$ is generally observed in chromium poisoning experiments. By extension, the formation of $(\mathrm{Cr}, \mathrm{Mn})_{3} \mathrm{O}_{4}$ is accompanied by the formation of $(\mathrm{La}, \mathrm{Sr})(\mathrm{Cr}, \mathrm{Mn}) \mathrm{O}_{3}$ according to the equations below [2], which describe the reaction of $(\mathrm{La}, \mathrm{Sr}) \mathrm{MnO}_{3}$ with solid (1) or gaseous (2) chromium species:

$$
1.5 \mathrm{Cr}_{2} \mathrm{O}_{3(\mathrm{~s})}+3(\mathrm{La}, \mathrm{Sr}) \mathrm{MnO}_{3} \rightarrow 3(\mathrm{La}, \mathrm{Sr})\left(\mathrm{Cr}_{1-\mathrm{y}} \mathrm{Mn}_{\mathrm{y}}\right) \mathrm{O}_{3}+\left(\mathrm{Cr}_{\mathrm{y}} \mathrm{Mn}_{1-\mathrm{y}}\right)_{3} \mathrm{O}_{4}+0.25 \mathrm{O}_{2}
$$




$$
3 \mathrm{CrO}_{3(\mathrm{~g})}+3(\mathrm{La}, \mathrm{Sr}) \mathrm{MnO}_{3} \rightarrow 3(\mathrm{La}, \mathrm{Sr})\left(\mathrm{Cr}_{1-\mathrm{y}} \mathrm{Mn}_{\mathrm{y}}\right) \mathrm{O}_{3}+\left(\mathrm{Cr}_{\mathrm{y}} \mathrm{Mn}_{1-\mathrm{y}}\right)_{3} \mathrm{O}_{4}+2.5 \mathrm{O}_{2}
$$

Another possible route to $(\mathrm{La}, \mathrm{Sr})(\mathrm{Cr}, \mathrm{Mn}) \mathrm{O}_{3}$ was raised in a study considering the thermodynamics of chromium poisoning in SOFC cathodes [21], where it was predicted that at typical SOFC operating temperatures chromium can be dissolved into $(\mathrm{La}, \mathrm{Sr}) \mathrm{MnO}_{3}$ without forming other phases and with the corresponding advent of A-site deficiency according to:

$$
\left(\mathrm{La}_{0.8} \mathrm{Sr}_{0.2}\right) \mathrm{MnO}_{3}+0.1 \mathrm{CrO}_{3(\mathrm{~g})} \rightarrow 1.1\left(\mathrm{La}_{0.8} \mathrm{Sr}_{0.2}\right)_{0.909}\left(\mathrm{Cr}_{0.091} \mathrm{Mn}_{0.909}\right) \mathrm{O}_{3}
$$

Although thermodynamically predicted, chromium substitution into the perovskite lattice of $(\mathrm{La}, \mathrm{Sr}) \mathrm{MnO}_{3}$ has not been observed during the course of chromium poisoning experiments, suggesting slow kinetics [21]. Assuming slow kinetics, the non-observation of chromium-substituted ( $\mathrm{La}, \mathrm{Sr}) \mathrm{MnO}_{3}$ is not surprising considering that exposure times in all but one (Menzler et al [13], 8,000 h exposure time) of the above-cited chromium poisoning studies were $\leq 3,000 \mathrm{~h}$ and therefore short compared to SOFC system lifetime requirements, which exceed $40,000 \mathrm{~h}[20,22]$. Moreover, it would be nearly impossible to distinguish any chromium-substituted $(\mathrm{La}, \mathrm{Sr}) \mathrm{MnO}_{3}$ formed from $(\mathrm{La}, \mathrm{Sr}) \mathrm{MnO}_{3}$ using the common technique of $\mathrm{X}$-ray diffractometry (XRD), since these materials are isostructural on account of the fact that the ionic radii [23] of VI-coordinate (high spin) $\mathrm{Mn}^{3+}(0.645 \AA)$ and $\mathrm{Cr}^{3+}(0.615 \AA)$ are similar. Considering that SOFC system lifetime requirements are quite long, the thermodynamically predicted and seemingly slow process of chromiumsubstituted ( $\mathrm{La}, \mathrm{Sr}) \mathrm{MnO}_{3}$ formation could be a source of performance degradation underlying more overt and well-known chromium poisoning mechanisms.

To study in isolation the possible degradation of SOFC cathode performance due to the reaction of chromium species with $(\mathrm{La}, \mathrm{Sr}) \mathrm{MnO}_{3}$, the present study considers the electronic conductivity $(\sigma)$ and electrochemical oxygen reduction activity of $(\mathrm{La}, \mathrm{Sr}) \mathrm{MnO}_{3}$ into which chromium was systematically substituted at low levels $(\leq 0.1)$ for manganese on the B-site. Regarding electronic properties, these materials differ 
considerably compared to widely utilised LSCM SOFC electrode materials, such as the $\mathrm{La}_{0.75} \mathrm{Sr}_{0.25} \mathrm{Cr}_{0.5} \mathrm{Mn}_{0.5} \mathrm{O}_{3}$ composition reported by Tao and Irvine [24], since the low-level concentrations of chromium on the B-site are well below the percolation threshold (0.33). Electronic conductivity was considered using the results of electrical conductivity measurements, since the ionic conductivity of $(\mathrm{La}, \mathrm{Sr}) \mathrm{MnO}_{3}$ is known to be several orders of magnitude lower in comparison [25]. In order to achieve the aims of the present study the $\left(\mathrm{La}_{0.8} \mathrm{Sr}_{0.2}\right)_{0.98} \mathrm{Cr}_{x} \mathrm{Mn}_{1-x} \mathrm{O}_{3}$ model series $(x=0,0.02,0.05$ or 0.1$)$ was investigated in air over the temperature range $850-650{ }^{\circ} \mathrm{C}$. The somewhat modest maximum extent of chromium substitution $(x=0.1)$ was chosen since equation (3) [21] suggests that a substitution level approaching $10 \%$ is thermodynamically possible.

\section{Experimental}

The $\left(\mathrm{La}_{0.8} \mathrm{Sr}_{0.2}\right)_{0.98} \mathrm{Cr}_{x} \mathrm{Mn}_{1-x} \mathrm{O}_{3}$ model series was prepared via solid state synthesis using stoichiometric amounts of $\mathrm{La}_{2} \mathrm{O}_{3}, \mathrm{SrCO}_{3}, \mathrm{Cr}_{2} \mathrm{O}_{3}$ and $\mathrm{Mn}_{2} \mathrm{O}_{3}$. Prior to accurate weighing of precursor powders, $\mathrm{La}_{2} \mathrm{O}_{3}$ was decarbonised at $900{ }^{\circ} \mathrm{C}$, while $\mathrm{SrCO}_{3}, \mathrm{Cr}_{2} \mathrm{O}_{3}$ and $\mathrm{Mn}_{2} \mathrm{O}_{3}$ were dried at $300{ }^{\circ} \mathrm{C}$. Powders were mixed in a mortar and pestle with acetone and dried before calcination at $1000{ }^{\circ} \mathrm{C}$ for $12 \mathrm{~h}$. Calcined powder mixtures were ground in a mortar and pestle followed by uniaxial pressing under $150 \mathrm{MPa}$ load into pellets that were fired at $1300{ }^{\circ} \mathrm{C}$ for $12 \mathrm{~h}$. Fired pellets were ground in a mortar and pestle and resultant powders planetary ball-milled in isopropanol using $\varnothing 3 \mathrm{~mm}$ zirconia balls at $400 \mathrm{rpm}$ for $1 \mathrm{~h}$. Recovered powders were uniaxially pressed, fired and milled as above. An additional planetary ball-milling step in isopropanol was carried out using $\varnothing 1 \mathrm{~mm}$ zirconia balls at $400 \mathrm{rpm}$ for $0.5 \mathrm{~h}$ in order to lower particle size and therefore improve sinterability of final powders. Room temperature powder XRD was performed on a PANalytical X'Pert Pro diffractometer operated in reflection mode using $\mathrm{Cu}-\mathrm{K} \alpha_{1}$ radiation, $2 \theta$ range $20-80^{\circ}, 0.017^{\circ}$ step and $1 \mathrm{~h}$ scan duration.

Pellets for van der Pauw electrical conductivity measurements were prepared by mixing $3.3 \mathrm{~g}$ $\left(\mathrm{La}_{0.8} \mathrm{Sr}_{0.2}\right)_{0.98} \mathrm{Cr}_{x} \mathrm{Mn}_{1-x} \mathrm{O}_{3}$ powder, 3x drops of $\mathrm{KD}-6$ liquid polymeric surfactant and acetone in a mortar and pestle. Dried mixtures were uniaxially pressed under $150 \mathrm{MPa}$ load into pellets that were fired at $1300{ }^{\circ} \mathrm{C}$ for 12 h, yielding pellets with 78-84 \% relative density. Measurements were performed under constant air flow 
on cooling from $850^{\circ} \mathrm{C}$ to $650^{\circ} \mathrm{C}$ using Pt wire connections, a ProboStat ${ }^{\mathrm{TM}}$ unit (NorECs AS) inserted into the hot zone of a vertical furnace, and a multimeter (Keithley 2750).

Symmetrical cells for electrochemical oxygen reduction activity measurements were prepared in triplicate and based on a dense 8 mol.\% yttria-stabilsed zirconia (YSZ) electrolyte with electrodes on either side composed of active composite $(\mathrm{La}, \mathrm{Sr})(\mathrm{Cr}, \mathrm{Mn}) \mathrm{O}_{3} / \mathrm{YSZ}$ and current-collecting pure $(\mathrm{La}, \mathrm{Sr})(\mathrm{Cr}, \mathrm{Mn}) \mathrm{O}_{3}$ layers. Composite $(\mathrm{La}, \mathrm{Sr})(\mathrm{Cr}, \mathrm{Mn}) \mathrm{O}_{3} / \mathrm{YSZ}$ active layers were used to make the experiments technologically relevant and to minimise possible microstructural variation brought about by any changes in the sinterability of $\left(\mathrm{La}_{1} \mathrm{Sr}\right) \mathrm{MnO}_{3}$ upon chromium substitution. The architecture of symmetrical cells was $(\mathrm{La}, \mathrm{Sr})(\mathrm{Cr}, \mathrm{Mn}) \mathrm{O}_{3} /\left((\mathrm{La}, \mathrm{Sr})(\mathrm{Cr}, \mathrm{Mn}) \mathrm{O}_{3} / \mathrm{YSZ}\right) / / \mathrm{YSZ} / /\left((\mathrm{La}, \mathrm{Sr})(\mathrm{Cr}, \mathrm{Mn}) \mathrm{O}_{3} / \mathrm{YSZ}\right) /(\mathrm{La}, \mathrm{Sr})(\mathrm{Cr}, \mathrm{Mn}) \mathrm{O}_{3} . \quad$ The $\quad$ extent $\quad$ of chromium substitution in the active and current collecting layers was matched for each value of $x$ in the $\left(\mathrm{La}_{0.8} \mathrm{Sr}_{0.2}\right)_{0.98} \mathrm{Cr}_{x} \mathrm{Mn}_{1-x} \mathrm{O}_{3}$ model series. Dense YSZ pellets with $\varnothing 20 \mathrm{~mm}$ and $2 \mathrm{~mm}$ thickness were prepared by uniaxially pressing $3.6 \mathrm{~g}$ commercial YSZ powder under $35 \mathrm{MPa}$ load followed by firing at $1450{ }^{\circ} \mathrm{C}$ for $12 \mathrm{~h}$. For each composite $(\mathrm{La}, \mathrm{Sr})(\mathrm{Cr}, \mathrm{Mn}) \mathrm{O}_{3} / \mathrm{YSZ}\left(50: 50\right.$ by weight) and pure $(\mathrm{La}, \mathrm{Sr})(\mathrm{Cr}, \mathrm{Mn}) \mathrm{O}_{3}$ screen-printing ink 1.0 $\mathrm{g}$ ceramic was dispersed in acetone with $2 \mathrm{wt}$.\% KD-1 dispersant using an ultrasonic probe for $10 \mathrm{~min}$. To this dispersion was added $0.43 \mathrm{~g}$ vehicle consisting of $5 \mathrm{wt} \%$ poly(vinyl butyrate) in terpineol, giving a ceramic:vehicle weight ratio of 70:30. The mixture was magnetically stirred at room temperature overnight to evaporate the acetone and yield the final ink. Composite $(\mathrm{La}, \mathrm{Sr})(\mathrm{Cr}, \mathrm{Mn}) \mathrm{O}_{3} / \mathrm{YSZ}$ and pure $(\mathrm{La}, \mathrm{Sr})(\mathrm{Cr}, \mathrm{Mn}) \mathrm{O}_{3}$ inks were each screen-printed through a 325 mesh to $2 x$ layers thickness in $\varnothing 12 \mathrm{~mm}$ disc shape on either side of dense YSZ pellets with drying between the application of layers. Symmetrical cells were fired at $1000^{\circ} \mathrm{C}$ for 2 h. Cross-sectional scanning electron microscopy (SEM) of symmetrical cells indicated active and currentcollecting layer thicknesses ranging between 20-24 $\mu \mathrm{m}$ and 9-12 $\mu \mathrm{m}$, respectively. To assist current collection, gold paste was applied to symmetrical cells in a radial pattern and fired at $900{ }^{\circ} \mathrm{C}$ for $0.5 \mathrm{~h}$. A control Au/YSZ/Au symmetrical cell was also prepared to allow the contribution of the YSZ electrolyte, wires and contacts to ohmic resistance $\left(R_{s}\right)$ to be subtracted from the results obtained for $(\mathrm{La}, \mathrm{Sr})(\mathrm{Cr}, \mathrm{Mn}) \mathrm{O}_{3}$-based symmetrical cells. 
Electrochemical oxygen reduction activity measurements on triplicate symmetrical cells were performed under constant air flow on cooling from $850{ }^{\circ} \mathrm{C}$ to $650{ }^{\circ} \mathrm{C}$ using Pt wire connections, a ProboStat ${ }^{\mathrm{TM}}$ unit (NorECs AS) inserted into the hot zone of a vertical furnace, a frequency response analyser (Solartron SI 1260), an electrochemical interface (Solartron 1296) and SMaRT v3.0.1 software (Solartron). Electrochemical impedance spectroscopy (EIS) was carried out using $100 \mathrm{mV} \mathrm{AC}$ perturbation, $1 \mathrm{MHz}-0.2 \mathrm{~Hz}$ frequency range, and 3 cycles integration. The results of EIS measurements were analysed using ZView v2.80 software (Scribner Associates).

\section{Results and Discussion}

\subsection{X-ray diffractometry}

The XRD patterns of $\left(\mathrm{La}_{0.8} \mathrm{Sr}_{0.2}\right)_{0.98} \mathrm{Cr}_{x} \mathrm{Mn}_{1-x} \mathrm{O}_{3}$ powders prepared in air via solid state synthesis are presented in Fig. 1. Compositions were isostructural single phase perovskites with respect to XRD analysis, while the observed peak splitting was consistent with rhombohedral crystal symmetry.

\subsection{Electronic conductivity}

The substitution of $\mathrm{Sr}^{2+}$ for $\mathrm{La}^{3+}$ on the A-site of $\mathrm{LaMnO}_{3}$ is described by equation (4). In air, the lower

oxidation state of $\mathrm{Sr}^{2+}$ compared to $\mathrm{La}^{3+}$ is electrically compensated via oxidation of the manganese $\mathrm{B}$-site cation from 3+ to $4+$. The $\mathrm{Mn}_{\mathrm{Mn}}$ charge carrier makes $(\mathrm{La}, \mathrm{Sr}) \mathrm{MnO}_{3}$ an electronic conductor.

$$
2 \mathrm{SrO}+2 \mathrm{Mn}_{\mathrm{Mn}}^{\mathrm{x}}+1 / 2 \mathrm{O}_{2} \rightarrow 2 \mathrm{Sr}_{\mathrm{La}}^{\prime}+2 \mathrm{Mn}_{\mathrm{Mn}}^{\cdot}+3 \mathrm{O}_{\mathrm{O}}^{\mathrm{x}}
$$




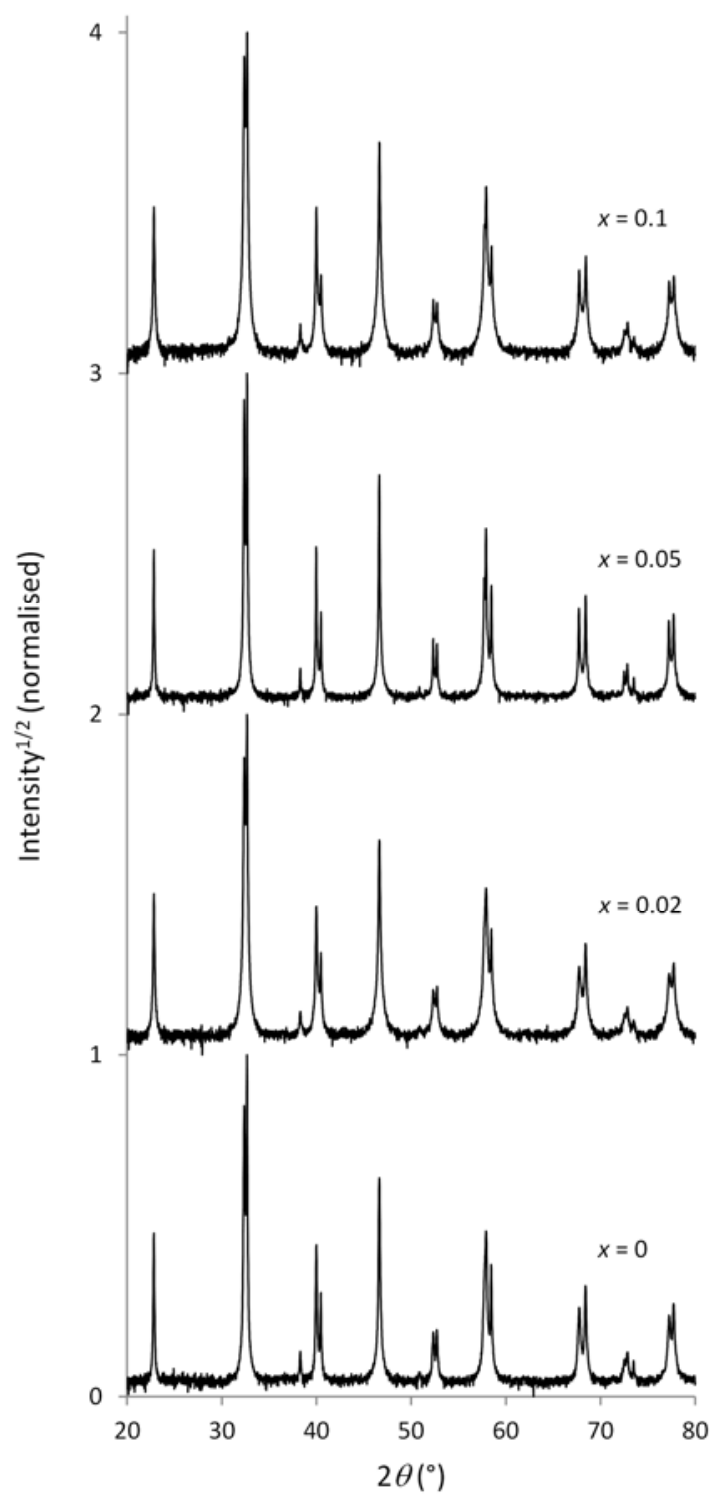

Fig. 1. X-ray diffraction patterns of $\left(\mathrm{La}_{0.8} \mathrm{Sr}_{0.2}\right)_{0.98} \mathrm{Cr}_{x} \mathrm{Mn}_{1-x} \mathrm{O}_{3}$ powders prepared in air via solid state synthesis, with extent of chromium substitution $(x)$ as indicated.

The electronic conductivity $(\sigma)$ of $\left(\mathrm{La}_{0.8} \mathrm{Sr}_{0.2}\right)_{0.98} \mathrm{Cr}_{x} \mathrm{Mn}_{1-x} \mathrm{O}_{3}$ pellets measured in air between $850-650{ }^{\circ} \mathrm{C}$ using the van der Pauw method is shown in Fig. 2. Electronic conductivity followed a small polaron hopping mechanism [25], while the data presented in Fig. 2 was fitted using equation (5), where $T=$ temperature, $E_{a}=$ activation energy and $\mathrm{R}=$ gas constant. 


$$
\sigma \mathrm{T}=\sigma_{0} \exp \left(-\mathrm{E}_{\mathrm{a}} / \mathrm{RT}\right)
$$

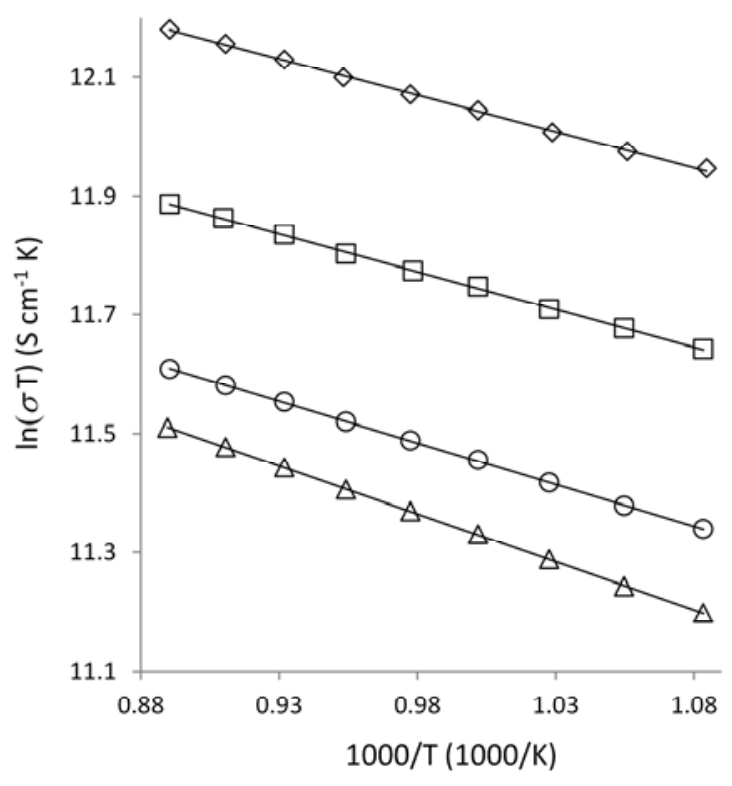

Fig. 2. Electronic conductivity $(\sigma)$ of $\left(\mathrm{La}_{0.8} \mathrm{Sr}_{0.2}\right)_{0.98} \mathrm{Cr}_{x} \mathrm{Mn}_{1-x} \mathrm{O}_{3}$ pellets measured in air between $850-650{ }^{\circ} \mathrm{C}$ using the van der Pauw method. $(\diamond) x=0,(\square) x=0.02,(\bigcirc) x=0.05,(\Delta) x=0.1$.

Low-level chromium substitution for manganese on the B-site of $\left(\mathrm{La}_{0.8} \mathrm{Sr}_{0.2}\right)_{0.98} \mathrm{MnO}_{3}$ resulted in a steady lowering of electronic conductivity, similar to that reported previously for low-level chromium-substituted $\mathrm{La}_{0.92} \mathrm{Sr}_{0.08} \mathrm{MnO}_{3}$ [26]. For example, $\sigma$ values at $850{ }^{\circ} \mathrm{C}$ of $174,129,98$ and $89 \mathrm{~S} \mathrm{~cm}^{-1}$ were measured for $x$ values of $0,0.02,0.05$ and 0.1 , respectively. In a real SOFC cathode such a lowering of electronic conductivity would result in raised ohmic losses and interfere with the supply of electrons to active sites for the oxygen reduction reaction (ORR), which would in turn both result in degradation of SOFC performance. However, it is reasonable to assume that the formation of more resistive $(\mathrm{La}, \mathrm{Sr})(\mathrm{Cr}, \mathrm{Mn}) \mathrm{O}_{3}$ in a real SOFC cathode would be largely limited to grain surfaces, and that the transport of electrons would therefore occur predominantly through more conductive $(\mathrm{La}, \mathrm{Sr}) \mathrm{MnO}_{3}$ grain cores. In turn, this suggests that the degradation of a real $(\mathrm{La}, \mathrm{Sr}) \mathrm{MnO}_{3} \mathrm{SOFC}$ cathode upon reaction with chromium species due to lowered electronic conductivity would not be as extensive as inferred by the results presented in Fig. 2 . 
Electronic conductivity is proportional to the product of the concentration and mobility of charge carriers ( $\left[\mathrm{Mn}_{\mathrm{Mn}}\right]$ and $\mu$, respectively). Charge carrier concentration is one of the constants that constitute the preexponential term $\sigma_{0}$ in equation (5) [25]. Therefore, to gauge variation in [ $\mathrm{Mn}_{\mathrm{Mn}}$ ] with the extent of chromium substitution in the $\left(\mathrm{La}_{0.8} \mathrm{Sr}_{0.2}\right)_{0.98} \mathrm{Cr}_{x} \mathrm{Mn}_{1-x} \mathrm{O}_{3}$ model series, In $\sigma_{0}$ values from Fig. 2 were plotted against $x$ (Fig. 3). Only a slight decrease in $\ln \sigma_{0}$ values with $x$ was observed, suggesting that $\left[\mathrm{Mn}_{\mathrm{Mn}}\right]$ was largely unchanged with extent of chromium substitution. Furthermore, $\left[\mathrm{Mn}_{\mathrm{Mn}}^{\cdot}\right]$ in $(\mathrm{La}, \mathrm{Sr}) \mathrm{MnO}_{3}$ is not expected to change with chromium substitution since manganese B-sites have a lower small polaron site energy compared to chromium B-sites [27], suggesting that charge compensation for the replacement of $\mathrm{La}^{3+}$ by $\mathrm{Sr}^{2+}$ on the A-site would occur exclusively through the formation of $\mathrm{Mn}_{\mathrm{Mn}}$. This has been confirmed by $\mathrm{X}$-ray absorption near edge structure spectroscopy of $\mathrm{La}_{1-x} \mathrm{Sr}_{x} \mathrm{Cr}_{0.5} \mathrm{Mn}_{0.5} \mathrm{O}_{3}$ compositions [27], where the $\mathrm{Cr} \mathrm{K}$ edge did not deviate with extent of strontium substitution and was consistent with $\mathrm{Cr}^{3+}$, while the $\mathrm{Mn} \mathrm{K}$ edge shifted upon strontium substitution indicating compensation at the manganese B-site. Based on experimental results obtained here and with reference to the literature, the observed steady lowering of electronic conductivity with $x$ for the $\left(\mathrm{La}_{0.8} \mathrm{Sr}_{0.2}\right)_{0.98} \mathrm{Cr}_{x} \mathrm{Mn}_{1-x} \mathrm{O}_{3}$ model series may therefore be attributed to lowered $\mu$, which in turn may be attributed to a reduction in the number of available small polaron hopping manganese B-sites.

$E_{a}$ for electronic conductivity calculated from the slopes of the $\ln (\sigma \mathrm{T})$ vs. 1000/T plots in Fig. 2 increased with extent of chromium substitution in the $\left(\mathrm{La}_{0.8} \mathrm{Sr}_{0.2}\right)_{0.98} \mathrm{Cr}_{x} \mathrm{Mn}_{1-x} \mathrm{O}_{3}$ model series, with values of $0.105,0.110,0.121$ and $0.139 \mathrm{eV}( \pm 0.001 \mathrm{eV})$ calculated for $x=0,0.02,0.05$ and 0.1 , respectively. The plot of these values in Fig. 3 shows a significant and steady rise in $E_{a}$ with increasing $x_{1}$ indicative of a raised barrier to thermally activated hopping of charge carriers. This may be attributed, as above, to a lowering of the number of available manganese B-sites for small polaron hopping. 


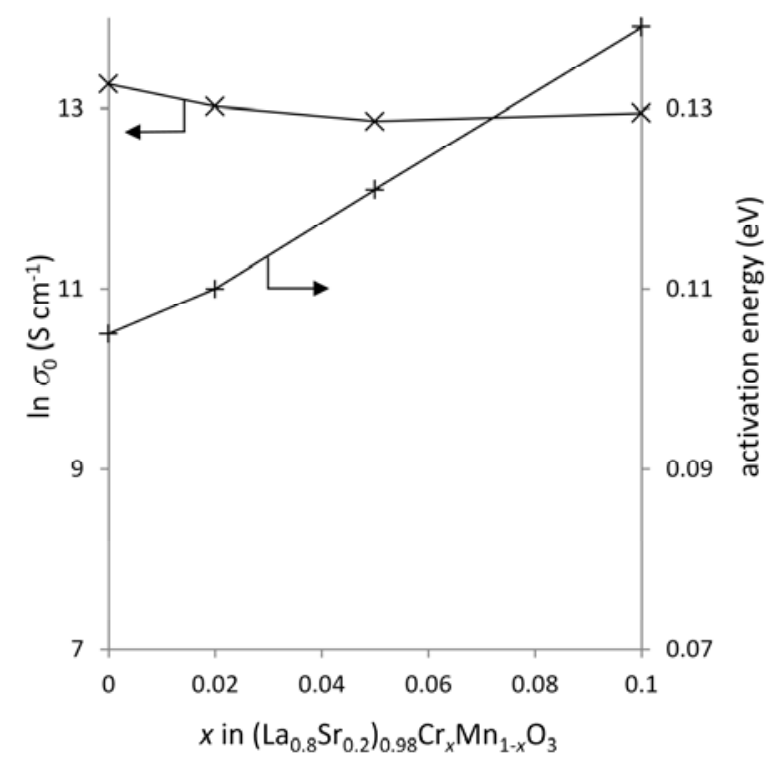

Fig. 3. In $\sigma_{0}(\times)$ and activation energy (+) from Fig. $2 \ln (\sigma \mathrm{T})$ vs. 1000/T plots for the $\left(\mathrm{La}_{0.8} \mathrm{Sr}_{0.2}\right)_{0.98} \mathrm{Cr}_{x} \mathrm{Mn}_{1-x} \mathrm{O}_{3}$ model series plotted against extent of chromium substitution $(x)$. Error bars (not shown) smaller than symbols.

\subsection{Electrochemical oxygen reduction activity}

For each value of $x$ in the $\left(\mathrm{La}_{0.8} \mathrm{Sr}_{0.2}\right)_{0.98} \mathrm{Cr}_{x} \mathrm{Mn}_{1-x} \mathrm{O}_{3}$ model series, at least two of the triplicate symmetrical cells exhibited near overlapping impedance spectra at all measurement temperatures. From these, one was randomly selected for presentation and detailed fitting as described below.

EIS analyses gauging the activity of the $\left(\mathrm{La}_{0.8} \mathrm{Sr}_{0.2}\right)_{0.98} \mathrm{Cr}_{x} \mathrm{Mn}_{1-x} \mathrm{O}_{3}$ model series towards electrochemical oxygen reduction were interpreted in accordance with the classification put forward by Jørgensen and Mogensen in 2001 [28] regarding processes on composite $\left(\mathrm{La}_{1} \mathrm{Sr}\right) \mathrm{MnO}_{3} / \mathrm{YSZ}$ electrodes. Based upon a thorough review of literature regarding the EIS analysis of $(\mathrm{La}, \mathrm{Sr}) \mathrm{MnO}_{3} / \mathrm{YSZ}$ electrodes, as well as new experimental data, Jørgensen and Mogensen identified processes " $A, B$ ", " $C$ ", " $D$ " and " $E$ ". Characteristic relaxation frequency $\left(v^{\star}\right)$ values observed in this study were consistent with processes $A, B$ and $C$, which relate to transport of oxide ions and/or oxygen intermediates across $(\mathrm{La}, \mathrm{Sr}) \mathrm{MnO}_{3} / \mathrm{YSZ}$ interfaces and through the YSZ phase of the 
composite, and to dissociative adsorption, transfer of species at TPBs, and surface diffusion, respectively. Process $D$, related to gas diffusion impedance, was also observed in this study, however was not taken into account since the magnitude of this process was observed to be invariant with respect to $x$ and temperature.

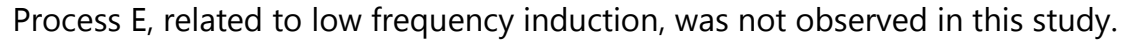

In addition to the deconvolution of process $A, B$ from process $C$, it was found that process $C$ could be further separated into two processes denoted here as $C_{1}$ and $C_{2}$. EIS spectra were therefore fitted using the equivalent circuit depicted in Fig. 4, where: $L=$ inductance; $R_{S}=$ ohmic resistance; $R_{A_{1}, B_{1}} R_{C_{1}}$ and $R_{C_{2}}=$ polarisation resistances corresponding to processes $A, B, C_{1}$ and $C_{2}$, respectively; and $C P E_{A, B}, C P E_{C_{1}}$ and $C P E_{C_{2}}$ = constant phase elements corresponding to processes $A, B, C_{1}$ and $C_{2}$, respectively. $L$ and $R_{s}$ elements and the $\mathrm{R}_{\mathrm{C}_{2}} / / C P E_{\mathrm{C}_{2}}$ unit were used in every fit, while the number of R//CPE units invoked was kept to a minimum. The $\mathrm{R}_{\mathrm{C}_{1}} / / \mathrm{CPE}_{\mathrm{C}_{1}}$ unit was used for all values of $x$ and for all temperatures except for $x=0$ and $\mathrm{T}=850,825^{\circ} \mathrm{C}$. The $\mathrm{R}_{\mathrm{A}, \mathrm{B}} / / \mathrm{CPE}_{\mathrm{A}, \mathrm{B}}$ unit was used for all values of $x$ and $\mathrm{T}=750-650{ }^{\circ} \mathrm{C}$. Where possible, the ability to deconvolute processes $A, B, C_{1}$ and $C_{2}$ was based on a minimum order-of-magnitude separation of associated relaxation frequencies. This is demonstrated in Table 1 , which shows $v^{\star}$ values observed at $750{ }^{\circ} \mathrm{C}$ for processes $A, B, C_{1}$ and $C_{2}$ depending on $x$. Fig. 5 shows an example deconvolution and overall fitting of EIS data measured in air at $650{ }^{\circ} \mathrm{C}$ for a symmetrical cell based on $\left(\mathrm{La}_{0.8} \mathrm{Sr}_{0.2}\right)_{0.98} \mathrm{Cr}_{0.1} \mathrm{Mn}_{0.9} \mathrm{O}_{3}$, using the full equivalent circuit depicted in Fig. 4.

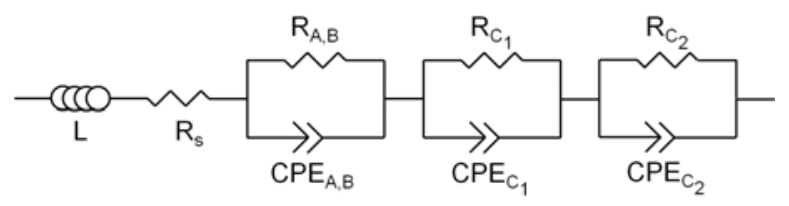

Fig. 4. Equivalent circuit used to fit electrochemical impedance spectroscopy data obtained for symmetrical cells based on the $\left(\mathrm{La}_{0.8} \mathrm{Sr}_{0.2}\right)_{0.98} \mathrm{Cr}_{x} \mathrm{Mn}_{1-x} \mathrm{O}_{3}$ model series. 
Table 1. Relaxation frequencies (measured at $750^{\circ} \mathrm{C}$ ) and activation energies corresponding to oxygen reduction reaction processes $A, B, C_{1}$ and $C_{2}$ for symmetrical cells based on the $\left(\mathrm{La}_{0.8} \mathrm{Sr}_{0.2}\right)_{0.98} \mathrm{Cr}_{x} \mathrm{Mn}_{1-x} \mathrm{O}_{3}$ model series.

\begin{tabular}{|l|l|l|l|l|l|l|l|l|}
\hline \multirow{2}{*}{ process } & \multicolumn{2}{|l|}{ relaxation frequency $(\mathrm{Hz})$} & \multicolumn{2}{l|}{ activation energy (eV) } \\
\cline { 2 - 9 } & $x=0$ & $x=0.02$ & $x=0.05$ & $x=0.1$ & $x=0$ & $x=0.02$ & $x=0.05$ & $x=0.1$ \\
\hline $\mathrm{A}, \mathrm{B}$ & $1.5 \times 10^{4}$ & $1.6 \times 10^{4}$ & $2.4 \times 10^{4}$ & $2.3 \times 10^{4}$ & $1.74 \pm 0.04$ & $1.70 \pm 0.08$ & $1.50 \pm 0.02$ & $2.00 \pm 0.05$ \\
\hline$C_{1}$ & $6.8 \times 10^{2}$ & $2.7 \times 10^{2}$ & $3.5 \times 10^{2}$ & $4.3 \times 10^{2}$ & $1.62 \pm 0.05$ & $1.50 \pm 0.04$ & $1.61 \pm 0.06$ & $1.72 \pm 0.06$ \\
\hline$C_{2}$ & $3.5 \times 10^{1}$ & $2.5 \times 10^{1}$ & $3.1 \times 10^{1}$ & $2.0 \times 10^{1}$ & $0.94 \pm 0.03$ & $1.29 \pm 0.04$ & $1.26 \pm 0.02$ & $1.23 \pm 0.03$ \\
\hline
\end{tabular}

Fig. 6 compares EIS analyses of symmetrical cells based on all $\left(\mathrm{La}_{0.8} \mathrm{Sr}_{0.2}\right)_{0.98} \mathrm{Cr}_{x} \mathrm{Mn}_{1-x} \mathrm{O}_{3}$ model series compositions measured in air at $850{ }^{\circ} \mathrm{C}$. Cross-sectional SEM (not shown) of symmetrical cells indicated qualitatively similar microstructures independent of $x$, such that EIS analyses could be interpreted in terms of changes in chemistry. The main distinction observed in Fig. 6 was the lower $R_{s}$ and polarisation resistance $\left(R_{p}\right)$ of unsubstituted $(\mathrm{La}, \mathrm{Sr}) \mathrm{MnO}_{3}(x=0)$ compared to the results observed for chromium-substituted compositions $\left(x=0.02,0.05\right.$ or 0.1 ). The higher $R_{s}$ of chromium-substituted compositions was broadly consistent with the steady decrease in electronic conductivity associated with substitution (Fig. 2), in conjunction with the fact that the radial pattern of gold paste employed only assisted current collection in symmetrical cells, meaning that lateral resistance of pure $(\mathrm{La}, \mathrm{Sr})(\mathrm{Cr}, \mathrm{Mn}) \mathrm{O}_{3}$ current collecting layers was a factor in determining $R_{s}$. The higher $R_{p}$ of chromium-substituted compositions was likely the result of interfered supply of electrons to TPBs and retardation of ORR processes following the substitution of catalytically active $\mathrm{Mn} \mathrm{B-site} \mathrm{cations} \mathrm{with} \mathrm{less} \mathrm{catalytically} \mathrm{active} \mathrm{Cr}$ cations. Translated to a real cathode, the increases in $R_{s}$ and $R_{p}$ observed here due to chromium substitution for manganese in ( $\left.\mathrm{La}, \mathrm{Sr}\right) \mathrm{MnO}_{3}$ would result in SOFC performance degradation. 

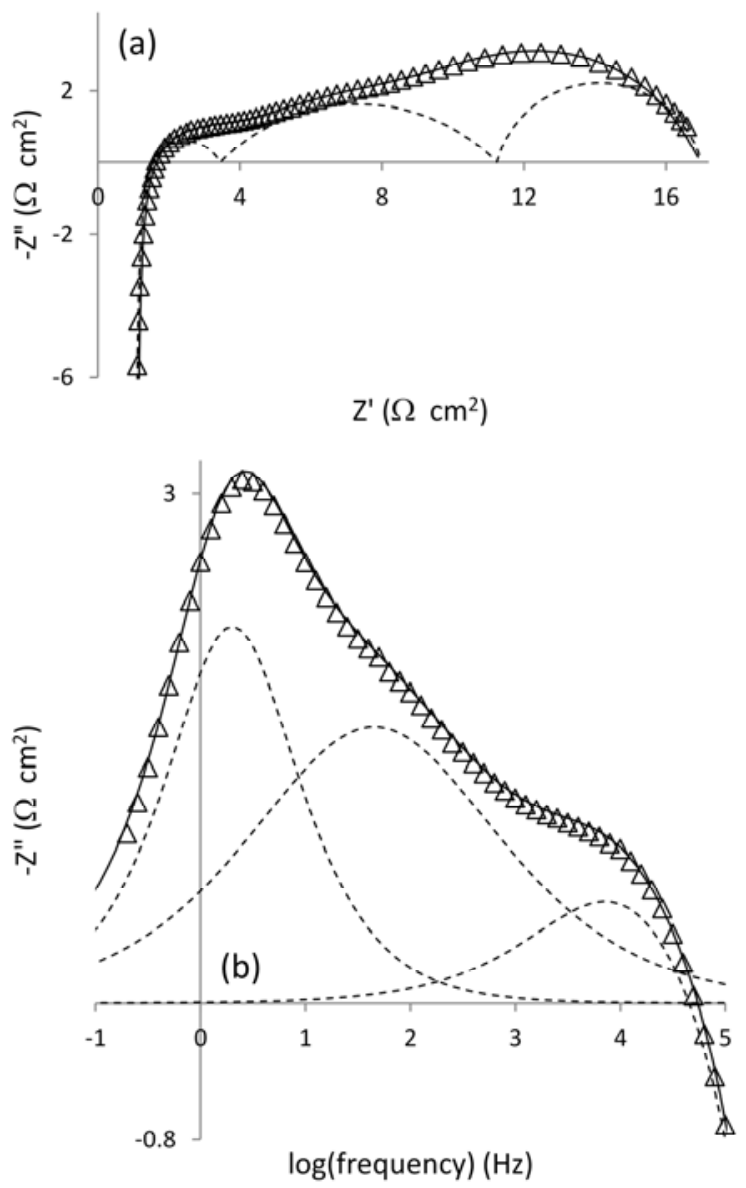

Fig. 5. Example deconvolution and overall fitting of (a) Nyquist and (b) Bode plots measured in air at $650{ }^{\circ} \mathrm{C}$ for a symmetrical cell based on $\left(\mathrm{La}_{0.8} \mathrm{Sr}_{0.2}\right)_{0.98} \mathrm{Cr}_{0.1} \mathrm{Mn}_{0.9} \mathrm{O}_{3}$. $(\Delta)$ experimental data, (---) individual components of fit, ( $(-)$ overall fit. Contribution of YSZ electrolyte, wires and contacts to ohmic resistance subtracted from data in (a).

A full comparison of the electrochemical oxygen reduction activity of all $\left(\mathrm{La}_{0.8} \mathrm{Sr}_{0.2}\right)_{0.98} \mathrm{Cr}_{x} \mathrm{Mn}_{1-x} \mathrm{O}_{3}$ model series compositions in air over the temperature range $850-650{ }^{\circ} \mathrm{C}$ is presented in Fig. 7, which shows separately the temperature dependencies of processes $A, B, C_{1}$ and $C_{2}$, and of the overall ORR. 

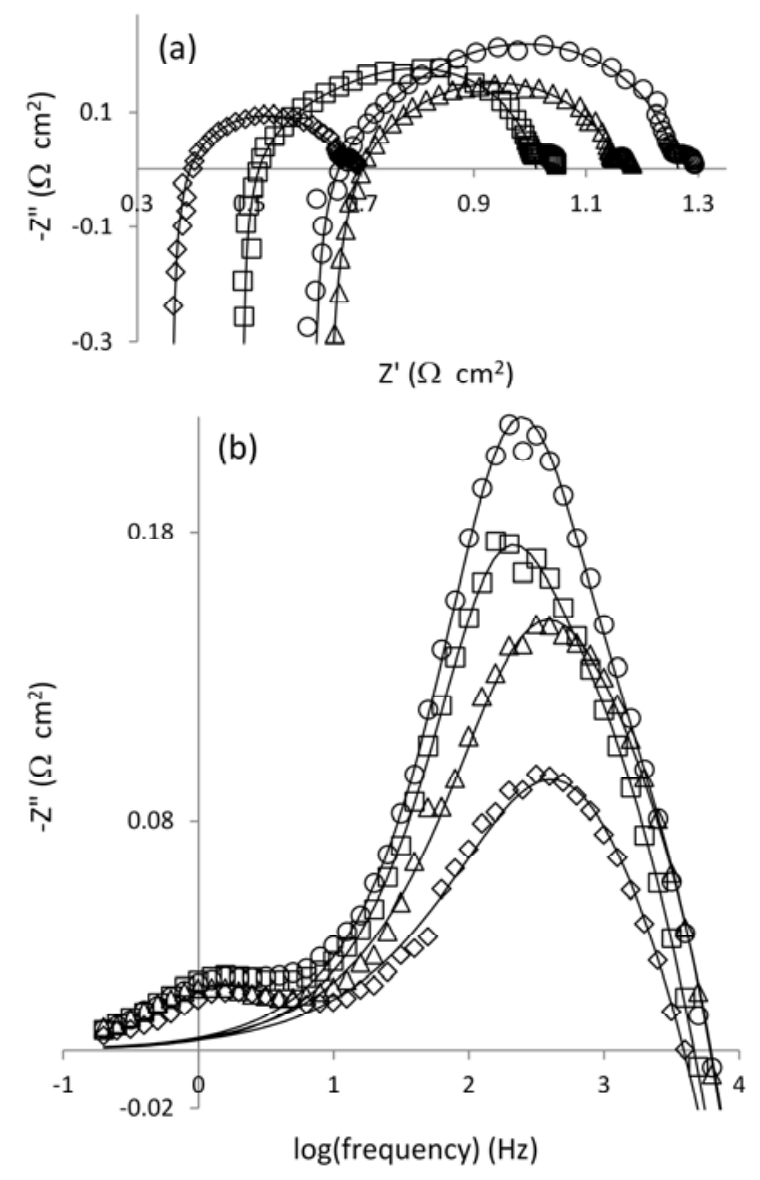

Fig. 6. Electrochemical impedance spectroscopy analysis in air at $850{ }^{\circ} \mathrm{C}$ of symmetrical cells based on $\left(\mathrm{La}_{0.8} \mathrm{Sr}_{0.2}\right)_{0.98} \mathrm{Cr}_{x} \mathrm{Mn}_{1-x} \mathrm{O}_{3}$ model series. (a) Nyquist plot. (b) Bode plot. $(\diamond) x=0,(\square) x=0.02,(O) x=0.05,(\Delta) x$ $=0.1$. Overall fits indicated by solid lines. Contribution of YSZ electrolyte, wires and contacts to ohmic resistance subtracted from data in (a). 


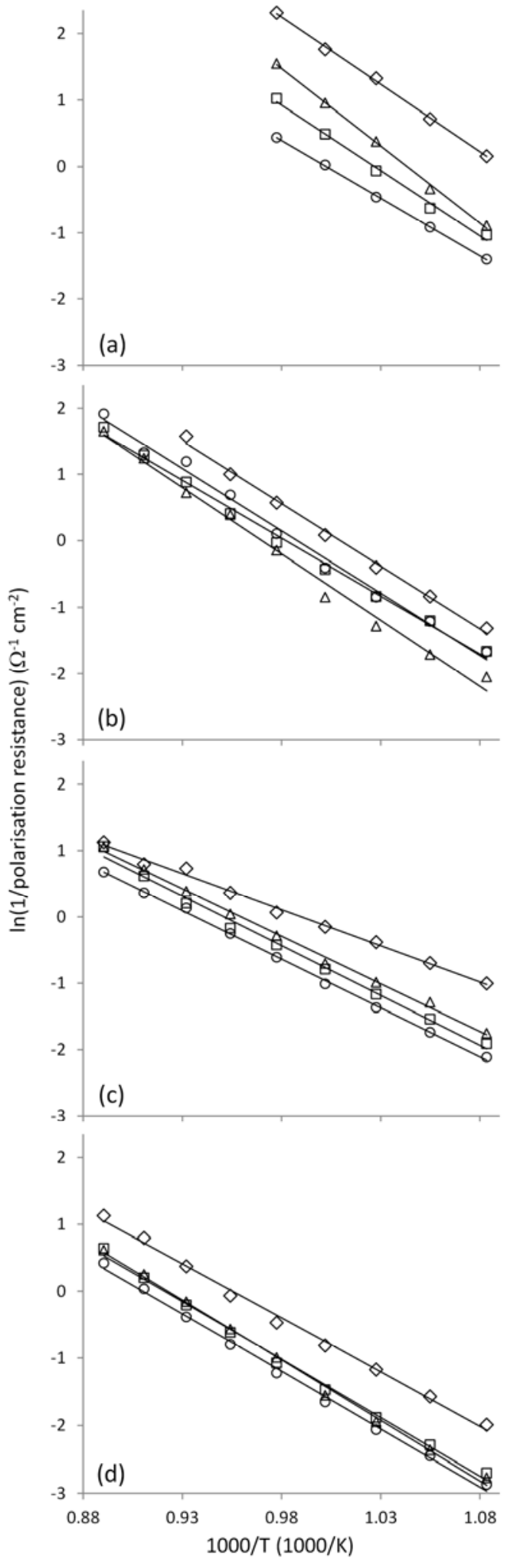

Fig. 7. Electrochemical oxygen reduction activity of $\left(\mathrm{La}_{0.8} \mathrm{Sr}_{0.2}\right)_{0.98} \mathrm{Cr}_{x} \mathrm{Mn}_{1-x} \mathrm{O}_{3}$ model series in air over the temperature range $850-650{ }^{\circ} \mathrm{C}$. (a) process $A, B$, (b) process $C_{1,}$ (c) process $C_{2}$ (d) overall oxygen reduction reaction. $(\diamond) x=0,(\square) x=0.02,(\bigcirc) x=0.05,(\Delta) x=0.1$. 
$\mathrm{R}_{\mathrm{A}, \mathrm{B}}$ in part associated with the transport of oxide ions and/or oxygen intermediates across ( $\left.\mathrm{La}, \mathrm{Sr}\right) \mathrm{MnO}_{3} / \mathrm{YSZ}$ interfaces, made up the smallest contribution to total $R_{p}$ for all compositions. Fig. $7(a)$ indicates that $R_{A, B}$ for unsubstituted ( $\mathrm{La}, \mathrm{Sr}) \mathrm{MnO}_{3}$ was considerably lower compared to chromium-substituted compositions, while no pattern in associated $E_{a}$ values (Table 1 ) could be identified. $R_{C_{1}}$, which may be related to dissociative adsorption, transfer of species at TPBs, or surface diffusion, was lower for unsubstituted (La, $\mathrm{Sr}) \mathrm{MnO}_{3}$ compared to chromium-substituted compositions (Fig. 7(b)). $E_{a}$ values associated with process $C_{1}$ (Table 1 ) for $x=0,0.05$ and 0.1 compositions were equal within experimental error, while that for the $x=0.02$ composition was slightly lower in comparison. In the absence of chromium substitution, $E_{a}$ for process $C_{2}$ was lower by between $0.29-0.35 \mathrm{eV}$ (Table 1 ), which in part led to similar $\mathrm{R}_{\mathrm{C}_{2}}$ values for all compositions at higher temperatures, while at lower temperatures $\mathrm{R}_{\mathrm{C}_{2}}$ values for the $x=0$ composition were substantially lower compared to $x=0.02,0.05$ and 0.1 compositions (Fig. 7(c)).

The temperature dependence of the overall ORR presented in Fig. 7(d) shows a clear distinction between the considerably lower total $\mathrm{R}_{\mathrm{p}}$ of unsubstituted ( $\left.\mathrm{La}, \mathrm{Sr}\right) \mathrm{MnO}_{3}$ compared to the rather similar results observed for chromium-substituted compositions. This was a manifestation of the consistently lower $R_{p}$ values observed for unsubstituted ( $\mathrm{La}, \mathrm{Sr}) \mathrm{MnO}_{3}$ with regard to each of the individual processes $A, B, C_{1}$ and $C_{2}$, as described in Fig. 7(a-c). Thus chromium substitution on the B-site of $(\mathrm{La}, \mathrm{Sr}) \mathrm{MnO}_{3}$ interfered with ORR processes including possibly transport of oxide ions and/or oxygen intermediates across ( $\mathrm{La}, \mathrm{Sr}) \mathrm{MnO}_{3} / \mathrm{YSZ}$ interfaces, dissociative adsorption, transfer of species at TPBs, and surface diffusion. Overall ORR $E_{a}$ values for $x=0,0.02,0.05$ and 0.1 compositions were $1.39 \pm 0.04,1.49 \pm 0.04,1.48 \pm 0.03$ and $1.54 \pm 0.03 \mathrm{eV}$, respectively. That is, the overall ORR $\mathrm{E}_{\mathrm{a}}$ value for unsubstituted $(\mathrm{La}, \mathrm{Sr}) \mathrm{MnO}_{3}$ was between $0.09-0.15 \mathrm{eV}$ lower compared to chromium substituted compositions, while $E_{a}$ values for $x=0.02,0.05$ and 0.1 compositions were equal within experimental error. Overall ORR $E_{a}$ values determined in this study were similar to those reported previously for similar ( $\mathrm{La}, \mathrm{Sr}) \mathrm{MnO}_{3} / \mathrm{YSZ}$ composite electrodes tested in air [29-32]. 


\section{Conclusions}

Chromium substitution for manganese on the $\mathrm{B}$-site of $(\mathrm{La}, \mathrm{Sr}) \mathrm{MnO}_{3}$ resulted in lowered $\sigma$ and raised $\mathrm{E}_{\mathrm{a}}$ with regard to electronic conductivity, and raised $R_{p}$ and $E_{a}$ associated with the overall ORR. In the case of electronic conductivity, lowered $\sigma$ and raised $\mathrm{E}_{\mathrm{a}}$ may be attributed to a lowering of the number of available small polaron hopping manganese B-sites. Regarding electrochemical oxygen reduction activity, raised $R_{p}$ and $E_{a}$ may be attributed to retardation of ORR processes including possibly transport of oxide ions and/or oxygen intermediates across ( $\mathrm{La}, \mathrm{Sr}) \mathrm{MnO}_{3} / \mathrm{YSZ}$ interfaces, dissociative adsorption, transfer of species at TPBs, and surface diffusion.

\section{Acknowledgements}

The authors thank the Swiss National Science Foundation (SNSF) Indo Swiss Joint Research Programme (ISJRP) for funding (Grant Agreement No. 138 864).

\section{References}

[1] S. Taniguchi, M. Kadowaki, H. Kawamura, T. Yasuo, Y. Akiyama, Y. Miyake, T. Saitoh, J. Power Sources 55 (1995) 73.

[2] S.P.S. Badwal, R. Deller, K. Foger, Y. Ramprakash, J.P. Zhang, Solid State Ionics 99 (1997) 297.

[3] S.P. Jiang, J.P. Zhang, L. Apateanu, K. Foger, J. Electrochem. Soc. 147 (2000) 4013.

[4] Y. Matsuzaki, I. Yasuda, J. Electrochem. Soc. 148 (2001) A126.

[5] K. Fujita, T. Hashimoto, K. Ogasawara, H. Kameda, Y. Matsuzaki, T. Sakurai, J. Power Sources 131 (2004) 270.

[6] S.C. Paulson, V.I. Birss, J. Electrochem. Soc. 151 (2004) A1961. 
[7] E. Konysheva, H. Penkalla, E. Wessel, J. Mertens, U. Seeling, L. Singheiser, K. Hilpert, J. Electrochem. Soc. 153 (2006) A765.

[8] E. Konysheva, J. Mertens, H. Penkalla, L. Singheiser, K. Hilpert, J. Electrochem. Soc. 154 (2007) B1252.

[9] T. Komatsu, R. Chiba, H. Arai, K. Sato, J. Power Sources 176 (2008) 132.

[10] J.J. Bentzen, J.V.T. Høgh, R. Barfod, A. Hagen, Fuel Cells 9 (2009) 823.

[11] C.J. Fu, K.N. Sun, X.B. Chen, N.Q. Zhang, D.R. Zhou, Electrochim. Acta 54 (2009) 7305.

[12] A. Neumann, N.H. Menzler, I. Vinke, H. Lippert, ECS Trans. 25 (2009) 2889.

[13] N.H. Menzler, I. Vinke, H. Lippert, ECS Trans. 25 (2009) 2899.

[14] J. Wu, C.D. Johnson, R.S. Gemmen, X. Liu, J. Power Sources 189 (2009) 1106.

[15] X. Chen, Y. Zhen, J. Li, S.P. Jiang, Int. J. Hydrogen Energy 35 (2010) 2477.

[16] T. Horita, Y. Xiong, H. Kishimoto, K. Yamaji, M.E. Brito, H. Yokokawa, J. Electrochem. Soc. 157 (2010) B614.

[17] J.A. Schuler, P. Tanasini, A. Hessler-Wyser, C. Comninellis, J. Van Herle, Electrochem. Commun. 12 (2010) 1682.

[18] T. Jin, K. Lu, Int. J. Hydrogen Energy 36 (2011) 4440.

[19] M. Kornely, A. Neumann, N.H. Menzler, A. Leonide, A. Weber, E. Ivers-Tiffée, J. Power Sources 196 (2011) 7203.

[20] J.A. Schuler, C. Gehrig, Z. Wuillemin, A.J. Schuler, J. Wochele, C. Ludwig, A. Hessler-Wyser, J. Van Herle, J. Power Sources 196 (2011) 7225.

[21] H. Yokokawa, T. Horita, N. Sakai, K. Yamaji, M.E. Brito, Y.P. Xiong, H. Kishimoto, Solid State Ionics 177 (2006) 3193.

[22] A. Faes, Z. Wuillemin, P. Tanasini, N. Accardo, J. Van Herle, J. Power Sources 196 (2011) 3553.

[23] R. Shannon, Acta Crystallogr., Sect. A: Found. 32 (1976) 751.

[24] S. Tao, J.T.S. Irvine, Nat. Mater. 2 (2003) 320.

[25] J.A.M. van Roosmalen, J.P.P. Huijsmans, L. Plomp, Solid State Ionics 66 (1993) 279.

[26] M. Mori, N. Sakai, T. Kawada, H. Yokokawa, M. Dokiya, Denki Kagaku 58 (1990) 528.

[27] S.M. Plint, P.A. Connor, S. Tao, J.T.S. Irvine, Solid State Ionics 177 (2006) 2005. 
[28] M.J. Jørgensen, M. Mogensen, J. Electrochem. Soc. 148 (2001) A433.

[29] M. Mogensen, S. Skaarup, Solid State Ionics 86-88 (1996) 1151.

[30] E.P. Murray, T. Tsai, S.A. Barnett, Solid State Ionics 110 (1998) 235.

[31] S. Wang, Y. Jiang, Y. Zhang, J. Yan, W. Li, J. Electrochem. Soc. 145 (1998) 1932.

[32] S.R. Gamble, J.T.S. Irvine, Solid State Ionics 192 (2011) 394. 